九州大学学術情報リポジトリ

Kyushu University Institutional Repository

\title{
Development of a Web-Based Video Direct e- Commerce System of Agricultural Products
}

Lee, Kang Oh

Foodsafety team, Korea Information Center for Agriculture, Forestry and Fisheries

Nakaji, Ke i

Laboratory of Agricultural Ecology, Division of Agronomy \& Environmental Sciences, Department of Agro-environmental Sciences, Faculty of Agriculture, Kyushu University

https://doi.org/10.5109/19538

出版情報: 九州大学大学院農学研究院紀要. 56 (1)，pp. 109-114，2011-02. Faculty of Agriculture， Kyushu University

バージョン：

権利関係 : 


\title{
Development of a Web-Based Video Direct e-Commerce System of Agricultural Products
}

\author{
Kang Oh LEE ${ }^{1 *}$ and Kei NAKAJI ${ }^{2}$ \\ ${ }^{1}$ Foodsafety team, Korea Information Center for Agriculture, Forestry and Fisheries, Korea \\ ${ }^{2}$ Laboratory of Agricultural Ecology, Division of Agronomy \& Environmental Sciences, \\ Department of Agro-environmental Sciences, Faculty of Agriculture, \\ Kyushu University, Fukuoka 811-2307, Japan \\ (Received October 29, 2010 and accepted November 8, 2010)
}

\begin{abstract}
A web-based video direct e-commerce system was developed to solve the problems in the internet shopping and to increase trust in safety and quality of agricultural products from consumers. We found that the newly developed e-commerce system could overcome demerits of the internet shopping and give consumers same effects as purchasing products offline. Producers could have opportunities to explain products and to talk to customers and get increased income because of maintaining a certain number of fixed consumers. Customers could purchase safe agricultural products with trusts based on direct conversation with producers. However, farmers' unfamiliarity for the information use and poor IT network infrastructure are needed to be improved in priority.
\end{abstract}

\section{INTRODUCTION}

Development of information technology (IT) has led to numerous changes in our lives. Especially, shopping, banking, cultural experiences, works, education, video meeting, etc. can be performed in a virtual space throughout the internet. The internet has occupied in our lives with a great portion at present. KRNIC reported that internet users (more than 3 years old) in Korea were more than 36,580,000 (NIA, 2009), and a percentage of using the internet was 77.6\%. Moreover, online home shopping has been rapidly increased on a basis of these internet users, and considerable research has been conducted (Park, 2001). Based on the survey on the electronic commerce and cyber trends (Statistics Korea, 2010), the volume of business for electronic commerce (e-commerce) and for online shopping were 206 trillion and 5981 billion wons, respectively.

However, although using e-commerce is very convenient due to development of the internet, there are several demerits in e-commerce. For example, infrastructure for information, information ethics, trust from customers due to non-face to face transactions, information for products, standardization of product quality and relevant laws are currently lacking in e-commerce (Lee et al., 2000). It is highly possible to happen for cheat, fraud, illegal transactions, etc. in e-commerce because the sales are conducted without knowing faces of each other unlike traditional shopping. Moreover, it is very often that customers are not satisfied with products after receiving them because the products are not same as the expectation from pictures and descriptions

1 Foodsafety team, Korea Information Center for Agriculture, Forestry and Fisheries, Korea

${ }^{2}$ Laboratory of Agricultural Ecology, Division of Agronomy \& Environmental Sciences, Department of Agro-environmental Sciences, Faculty of Agriculture, Kyushu University, Fukuoka 811-2307, Japan

* Corresponding author (E-mail: leeko2@affis.net) on the internet. There are several legal protective ways to compensate for the loss of consumers, however, the customers who experienced those cases would not easily trust e-commerce. Korean government has extensively tried to solve these problems.

Fair Trade Commission has announced the "Act on Consumer Protection in Electronic Commerce" and presented several ways to minimize consumers' losses and to stimulate e-commerce (Lee et al., 2004; Kim, 2002). It is required a new marketing system which can recover trust for products from consumers and maintain a certain number of consumers.

We developed a web-based direct e-commerce system by applying communications from both sides to overcome demerits of e-commerce and to protect consumers' right. A video direct e-commerce system can help producers keep a certain number of consumers by strengthening trust between them. Consumers can see agricultural products directly and have conversations with producers, so that consumers can purchase the products with assurance.

\section{MATERIALS AND METHODS}

\section{Description of a web-based video direct e-com- merce system}

A web-based video direct e-commerce system is the internet based system. The pronounced feature of this system is face-to-face conversation between producers (farmers) and consumers. Producers have opportunities to explain their products according to consumers' inquiries, and consumers can directly see and ask questions to producers about the products which they are interested in. This system is a changing trend of e-commerce for the next generation from static e-commerce. Fig. 1 is a diagram for a video direct e-commerce system. Both producers and consumers can use the online market for direct e-commerce after logging-in the web site. Producers can open the market by registering 
agricultural products. Consumers search and enter an opened market. In the market, consumers can listen to detail explanation about the products and get answers about what they are curious about. The products are delivered to the customers' places. This system is a both sided system to overcome defects in a one-way marketing system in e-commerce.

\section{Development of a web-based video direct e-com- merce system}

\section{1) Basic composition and features of the system}

A web-based video direct e-commerce system was developed to enhance user's convenience and security with applications of network and video solution by Korea Information Center for Agriculture (KICAFF) in 2005. Producers and consumers can access to the system anytime and anywhere. It is designed for easy and safe purchase, payment, and delivery of agricultural products.
The system was developed by using JSP and JAVA script language; database was established by Oracle; and a web-server, DB server, and video server was set up at KICAFF. Detail description for S/W and H/W compositions was presented in Table 1.

Video solution for the system was designed to use different video modes depending on the role (either producers or consumers). Producer can control all video screens to sell agricultural products through interactions with customers, and consumer can easily purchase the products by clicking a "BUY" button on the screen. A face to face video solution can be used by one producer and three consumers. A maximum of one hundred guests who are not shown on the video can participate in the market (Selling Channel) at maximum and can purchase products after participating video chats after permission from producers.

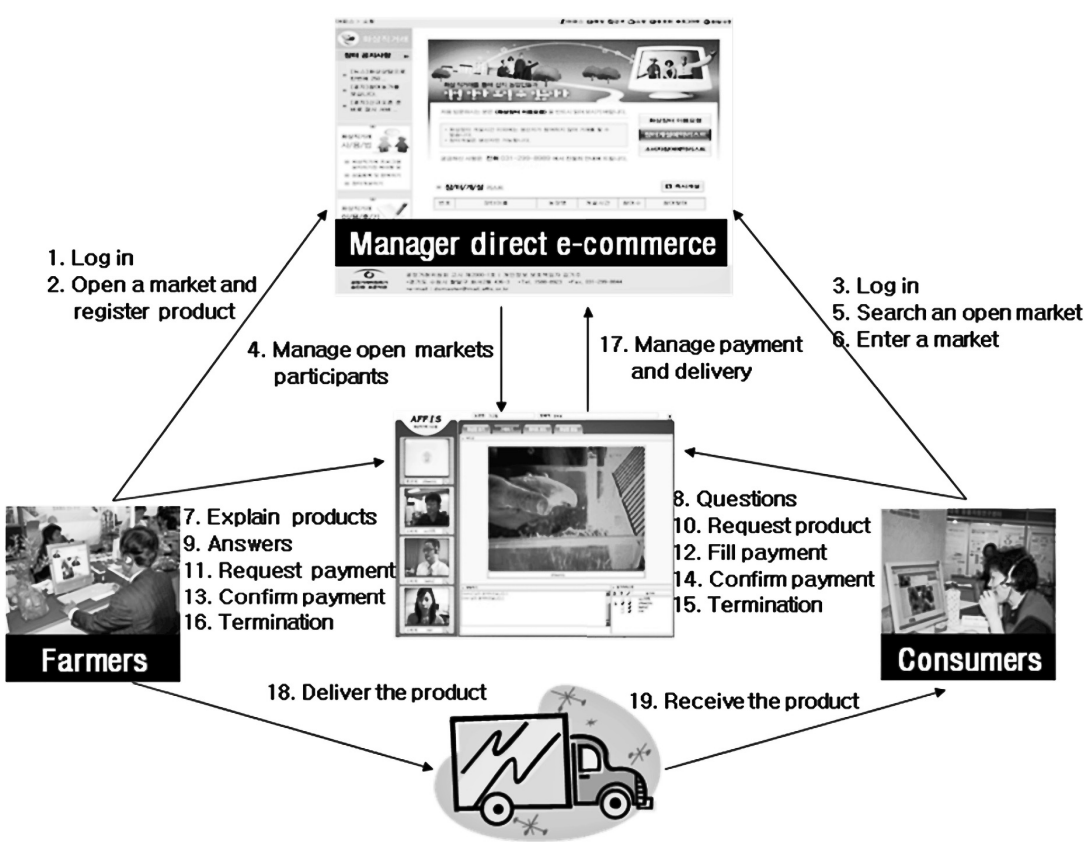

Fig. 1. A brief description for the web-based video direct e-commerce system.

Table 1. Basic composition and features of the web-based video direct e-commerce system

\begin{tabular}{|c|c|c|c|}
\hline \multicolumn{2}{|c|}{ S/W Configuration } & \multicolumn{2}{|r|}{ H/W Configuration } \\
\hline $\begin{array}{l}\text { Program } \\
\text { language }\end{array}$ & $\begin{array}{l}\text { JSP } \\
\text { JAVA } \\
\text { Oracle 9i }\end{array}$ & $\begin{array}{c}\text { Web } \\
\text { server }\end{array}$ & $\begin{array}{l}\text { CPU : PIII } 1.266 \mathrm{GHz}^{*} 2 \\
\text { Mem : } 2.5 \mathrm{~GB} \\
\text { DISK : } 36 \mathrm{~GB} * 1 \\
\text { OS : RedHat Linux } 8.0 \\
\text { WebServer : apache }\end{array}$ \\
\hline $\begin{array}{c}\text { DB } \\
\text { Management } \\
\text { Tool }\end{array}$ & Orange for ORACLE & $\begin{array}{c}\text { DB } \\
\text { server }\end{array}$ & $\begin{array}{l}\mathrm{CPU}: 400 \mathrm{MHz}^{*} 4 \\
\mathrm{CPU} \text { Board } 2 \text { 개 } \\
\text { Mem : } 6 \mathrm{~GB} \\
\text { DISK Array : } 18.2 \mathrm{~GB}^{*} 4, \mathrm{SUN} \\
\text { StorEdge T3WG : } 36 \mathrm{~GB} * 9 \\
\text { OS : Sun OS } 5.9 \\
\text { DBMS : Oracle } 9 \mathrm{i}\end{array}$ \\
\hline
\end{tabular}




\section{2) Use of web-based video direct e-commerce sys- tem}

Producers and consumers using the video direct e-commerce system can get same benefits like purchasing products at the offline market in a producing district. To use the video direct e-commerce system, both producers and consumers need to log-in at the main homepage of Sinsunmall (http://cam.sinsunmall. com). Producers open the market (Selling channel), and consumers can search opened markets, enter the interesting market, listen to detail description of the product from producers, and purchase the product. When users access Sinsunmall at the first time, the video solution is automatically installed. This video solution is automatically updated whenever the program is upgraded later.

Any producer who wants to sell agricultural products can open the market with both "Integrated certified ID" at Affis and "Management of Farm Marketing (Administrator)" at the homepage for their own farm. Consumers can search products from a list of opened markets. If a market is not opened, consumers can leave a message to urge producers to open the market by referring a list of participated farms.

\section{3) Main functions and characteristics of the web- based video direct e-commerce system}

The web-based video direct e-commerce system over the past static e-commerce makes it possible for consumers to purchase safe agricultural products after listening properties, growth environments, and history of the products directly from producers.

There are several main functions of the web-based video direct e-commerce system. First, producers (farmers) can reserve the market to open in advance. Producers register the product with information of name, price, and other detail properties of the product. The "Diary" function makes users search for markets opened by dates. Second, it is possible for producers (Reservation for market opening) and consumers (Reservation for participating in the market) to notify market information mutually. Moreover, consumers can search information for opened markets real time. Third, consumer's purchasing is linked to the e-commerce transaction system. Payment steps were minimized, and either card payment or online-direct credit as a payment option gives consumers convenience.

There are four major characteristics in a video direct e-commerce system. First, this system solved the problem of the past e-commerce which consumers can not really observe agricultural products. E-commerce consumers used to claim that the delivered product was not same as the product image on the web-site. However, the new system overcame this demerit of the past e-commerce system by showing the real images of the product and consulting with consumers. Second, farmers in the field can describe features of the products through video chat. It is possible for producers to explain and answer for questions, growth and history information, etc. to consumers sufficiently. Third, mutual sales marketing can be achieved through video chatting beyond the one-way marketing such as an exhibition of products in the past. Price flexibility is another benefit of the system. Through the communication between producers and consumers, consumers can purchase products with a lower price. Fourth, real time video images of producers can maximize trust and increase profits. Producers can enhance good relationships with consumers and manage a fixed number of consumers, so that it can contribute to high profits. Consumers can buy domestic agricultural products with assurance because they can check size, properties, and quality of products directly.

\section{RESULTS AND DISCUSSION}

1. Main homepage for the video direct e-commerce

Users are needed to log-in the homepage (http:// cam.sinsunmall.com) to use the video direct e-commerce system. Producers can open the market to sell the products, and consumers search opened markets, enter a market based on their needs, listen to explanation about the product, and purchase the product. Fig. 2 is a screen shot of the main homepage for the video direct e-commerce. Main menu is composed of Market, Video direct e-commerce, Notice, Review, and Support. Today's market shows available markets and agricultural products today, and users can check the reserved products for selling in the Tomorrow's market. The market is opened by producers, but the system is a both-directional system because consumers can also ask for the market opening in a Wish product tab.

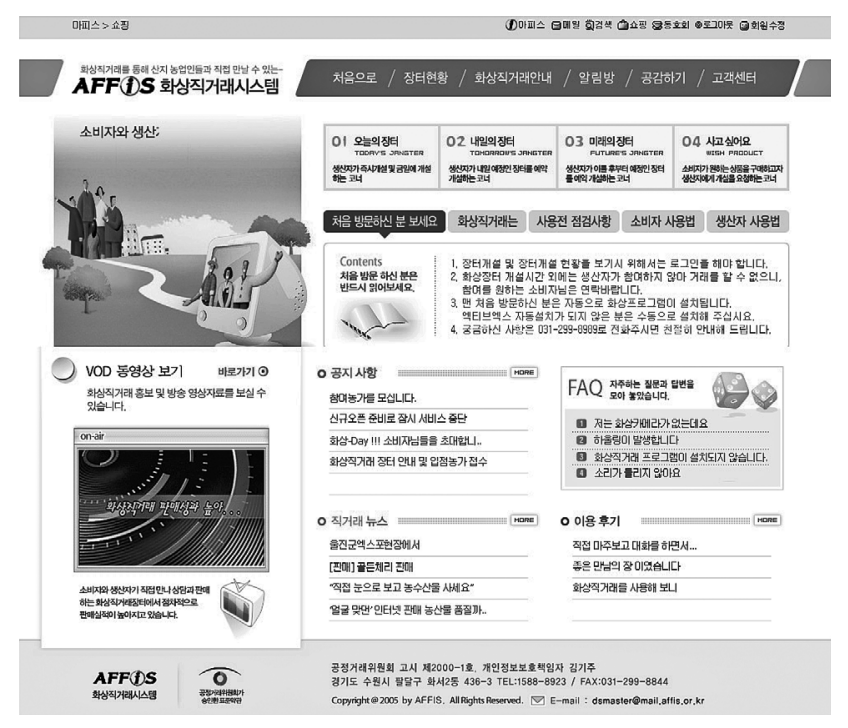

Fig. 2. Main screen on video direct e-commerce system.

\section{Opening Today's market}

To open a [Today's market], producers need to login the main homepage and click a [Open Today's Market] placed right on top of the [Today's market]. Producers need ID and password of "Management of Farm Marketing" on the screen of Administrator after clicking [Open Today's market]. On the reservation page for 
today, producers name on the market and click "Open", then Today's video direct e-commerce is opened. When producers are on-line at the "Today's video direct e-commerce", consumers enter the opened market by referring a list of opened market. Consumers click [Enter] to participate the market with a video of the consumers, or they can click [Observe] to see and listen to every interaction occurring in the market but these participants are not shown on video. Maximum guests for observing the market are 100 people, and only three people can participate in the market with a video. It is possible for producers to change guests to participants with a video on the market during the marketing process. Fig. 3 shows the screen shots for the [Open Today's market]. Fig. 3 (a) is [Open Today's market], (b) is typing ID and password of Administrator for agricultural products selling, (c) is naming on the [Today's market], and (d) is a list of opened markets today.
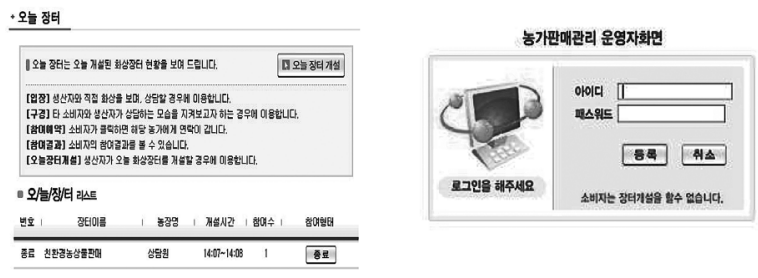

(a) Open Today's Market

(b) ID and password of Administrator for farmer

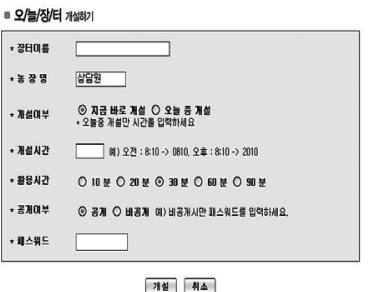

(c) Naming [Today's market]

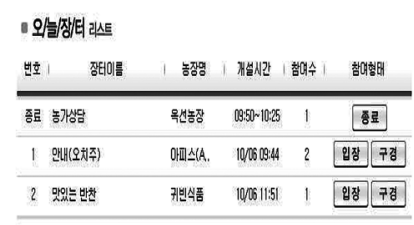

(d) a list of opened markets today

Fig. 3. An example of opening a market today on the video direct e-commerce system.

\section{Screens of a video direct e-commerce system}

The screens of a video direct e-commerce system for producers and consumers were designed differently to enhance users' convenience. Producers have overall power to control video solution and can limit some functions for consumers. Producers can use several functions such as view video screen, administrator screen (registration and retail of products), white board, same video screen, text chat. Producers can control functions for microphone, white board, change of participants, exclusion, etc for each consumer. Consumers' menu screen is changed according to the producers' operation, and available functions for consumers on the menu are "purchase" and "chatting."

Fig. 4 is a screen of a producer mode in the video direct e-commerce. While all tabs on the top are activated to use under the producer's mode, only "purchase" tab is activated under customer's mode. The [View video] tab under the producer mode is to see video of

customers. Basically, the first entered customer is shown on the big screen, but it is possible to change to other customers' video show on the big screen. [Administrator screen] is for registration of products and permission of selling, and it is required to have ID and password of "Selling and Management of farm products." [White board] is used for additional explanation of products, and text, figures, photos, documents, and data sheet can be shared with participants under this function. [Same video screen] can be used to make the customers' screen same as the screen of the producer to deliver important message. In addition, a list of all participants on the video direct e-commerce is shown right at the bottom, and customers who are not accessible to the microphone function can communicate through text chatting.

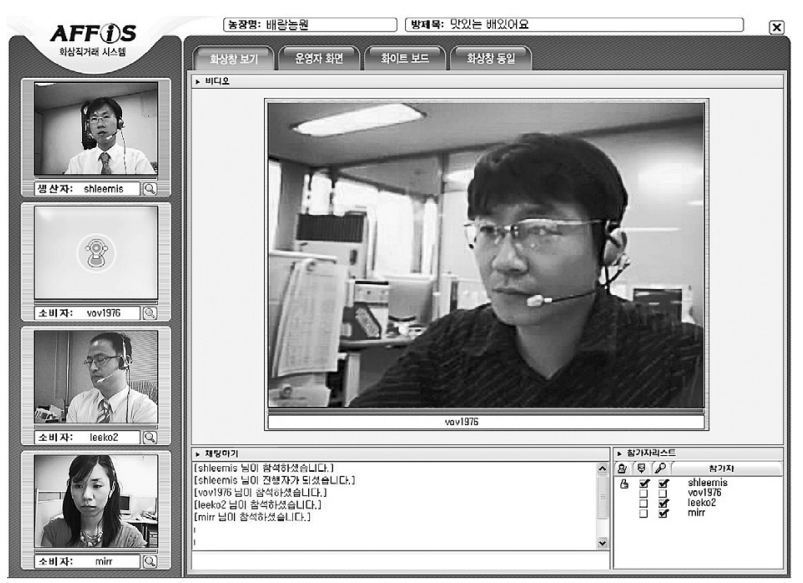

Fig. 4. Example screen of a video direct e-commerce system (Producer's mode).

\section{Purchasing products by a video direct e-com- merce}

To purchase products by a video direct e-commerce, first of all, producers should open the market, and then customers can enter the opened market to purchase products in need. Producers open the market on the video direct e-commerce system and use the "Administrator" mode to register products. After adding information about the product such as name, unit, size, and price of the products, producers need to click "Registration." After the registration is completed, a list of registered products is shown. To change information of the registered products, producers can modify or delete after checking the name of the products. When consumers ask for a reduced price, the producer can modify or change the price in a same method.

Consumers can enter the market after searching opened markets. It is possible for guests to participate in purchasing products through video when the producer allows them to participate. Customers can acquire correct information for the product by detail explanation and answers from producers and then decide to purchase the product. After clicking a "Purchase" button, 
customers write down information of requestor and receiver. Customers can pay for the product by either card payment or online-direct credit. When the producer confirms the payment completion, the product is delivered to the receiver by referring the information written. A manager of the video direct e-commerce system conducts market opening, management of participants, and management of payment for the purchasing product.

Fig. 5 shows steps for consumers to purchase a product by using a video direct e-commerce system. Fig. 5 (a) is a screen for registration by a producer, (b) is purchasing step for a consumer, (c) is a payment step of a consumer, and (d) is a screen of customer registration by a producer to deliver the product.
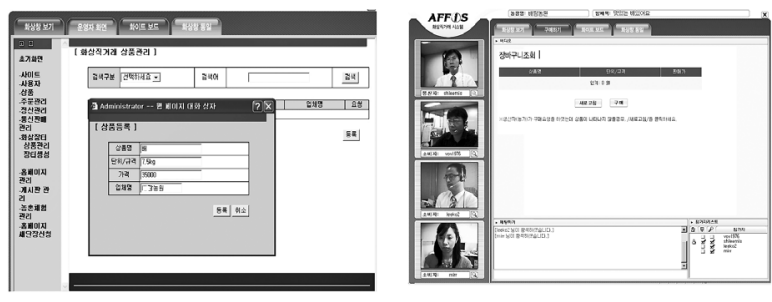

(a) Producer-Registration of the product

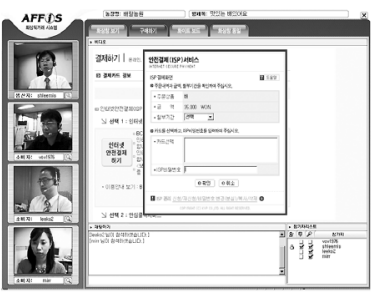

(c) Consumer - Payment

b) Consumer - First step of purchasing

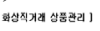
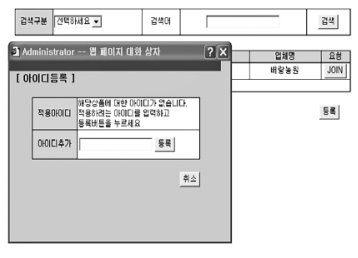

(d) Producer - Registration of customers

Fig. 5. Purchasing a product by using a video direct e-commerce system.

\section{Examples of application for a video direct e-commerce system}

A video direct e-commerce system has been used by 70 farms at the integrated shopping mall for agricultural products, i.e., Sinsunmal (http://www.sinsunmal. com). Each farmer as a producer selected specific time to open the market, and sales were started with explanation of each product at that time. An introduced video direct e-commerce system has made a link between producers and consumers without any restriction for time and space. Thus, producers could achieve improved profits, and consumers could purchase fresh agricultural products at a low price with trust. Here are opinions of producers using the system.

First, the best thing of the system is the opportunity to explain products of farmers by themselves. A recent media which reported about distrust for eco-friendly products increased distrust for the products dealt with e-commerce. It was very difficult to make customers understand differences between a received product and photos of the product on the web-site. However, the video direct e-commerce system made farmers enable to answer the questions of customers appropriately. As a result, customers could understand the product and trust farmers. Especially, face-to-face talking with customers is more persuasive to deliver the message about production history, quality and safety of the product compared to written description.

Second, it is expected to increase in selling by using a video direct $\mathrm{e}-$ commerce system. In the static e-commerce system, price is fixed, and customers decided whether they will buy the product or not based on the fixed price. However, it is possible to change price under the video direct e-commerce system, and this price flexibility can help customer urge to purchase products. For example, when the market for fruits and young trees of citrus were opened at the system, price of the young trees was 15,000 wons at the beginning. However, consumers argued that it was expensive, so the tree was sold with 12,000 wons. Like this case, the video direct e-commerce is beneficial to provide dealing opportunity for consumers through conversation.

Third, it was a great value for producers living in a distant district to meet consumers in big cities such as Seoul. It is not easy to meet consumers in Seoul by airplane travel. It is a burden for farmers in terms of time and money. However, it was possible to meet consumers without any restriction in time and place by using the video direct e-commerce system.

In addition to the beneficial effects of the system stated by farmers, more various effects are expected. For example, producers and consumers can meet anytime and anywhere through the system, so that consumers can purchase safe agricultural products. Mass selling and international sales would be possible in the future. The network through the system can establish good relationships between farmers and people who left their hometown.

Several things which need to be improved were found while the system was run. There were a time lag of 1 2 seconds in voices between producers and consumers and video interruption due to poor network infra structure in agricultural area and farmers' outdated computers. The frequency of using the system was low, and it was attributed to low computer proficiency of farmers, lack of consumers' facilities, and lack of advertisements for consumers. Because of these problems, the developed system has not been used for a long period, and the use is stopped at present.

\section{CONCLUSION AND SUMMARY}

A web-base video direct e-commerce system was developed to improve trust for the safety of agricultural products. As using a video direct e-commerce system, producers got trust from consumers for the products by face-to-face explaining production history, safety, ecofriendly growth, etc. Consumers could have opportunity to purchase products after understanding products well through the farmers' direct explanation. This was a new marketing strategy.

It was expected for the video direct e-commerce 
system to bring many changes in our lives by combining benefits from off-site markets where products were cultivated in the past and from a modern e-commerce. Producers could maintain a certain number of fixed customers through close relationships. The video direct e-commerce system could establish mutual marketing which producers and consumers could communicate through the video over the one-way marketing which was mainly operated by showing the products. In addition, customers could solve curiosities by video chatting and explanation by farmers on the field and purchase safe agricultural products at a lower price.

However, it is primarily required to improve network infra-structure in rural areas and to enhance farmers' ability to use information. At present, IT is widely used in many areas of agriculture. Although the developed system was not actively used, it is very worthwhile in terms of development and application of the agricultural products selling system.

\section{REFERENCES}

Chel Hee Kee and Gun Seop Sim, 1999 Agricultural situation and development of electronic direct marketing plan, Korea Agricultural Information Science Symposium, pp. 115-138

Dong Whan Kim, 2002 Satisfaction and dissatisfaction factors and success strategies of agro-food internet shopping malls, Korean journal of food marketing economics $\mathbf{1 9}(1)$, pp. 105125

D. P. Lee, J. H. Lee, C. G. Jun, K. S. Han and S. Y. Ryu, 2000 The study on the market situation and activation plan for the electronic commerce in agriculture, KREI Research Report

Ju Sek Park, 2001 The establishment of integrated information system of agricultural products for e-commerce, ARPC research report

Soon Seok Lee, Seok Kyu Yun, Yong Hee Kim and Gye Yup Lee, 2004 Activating programs of homepage operation and E-commerce for leading farmers, Korean journal of food marketing economics 21(1) pp. 121-134

Statistics Korea, 2010, 20102.4 quarter e-commerce and internet shopping trends, http://www.kostat.go.kr

KISA, 2009 Internet Use Survey 2009, http://www.kisa.or.kr/

Video Direct Marketing Systems, 2005 http://cam.sinsunmall. com/ 